\title{
Creating the Revolutionary Heroines: The Case of Female Terrorists of the PSR (Russia, Beginning of the 20th Century)
}

\author{
Nadezhda Petrusenko \\ Stockholm: Historiska institutionen, Stockholms Universitet 2017 \\ 354 sider. ISBN 9789177970811
}
Omtalt af Erik Kulavig [Licentiat, lektor, Institut for Historie, Syddansk Universitet, Kulavig@SDU.DK]

Jeg havde set frem til at læse om de kvindelige terrorrister, der hjemsøgte Rusland i slutningen af det nittende århundrede og $\mathrm{i}$ begyndelsen af det tyvende, men dem hører vi desværre ikke så meget om. Havde jeg været tilstrækkeligt opmærksom, da jeg læste bogens titel, kunne jeg have sagt det til mig selv på forhånd og være gået til værket med de rette forventninger og måske undgået noget af min skuffelse. Som titlen nemlig røber, og som man til overmål bliver overbevist om allerede i de indledende kapitler, er det nemlig ikke disse bemærkelsesværdige kvinder, der er bogens anliggende, men konstruktionerne af dem i form af selvbiografier og biografier, og det er jo som bekendt ikke det samme. Forfatteren, der er lektor i historie på Örebro Universitet, er dog ikke mere grebet af postmoderne konstruktionsteori, end hun kan gå med til, at der er en historisk virkelighed, der ligger under konstruktionerne, og som lader sig erkende. Det viser hun i det forholdsvis korte, men velskrevne afsnit om den historiske kontekst for terrorismen og altså for konstruktionerne. Og så til konstruktionerne.

De kvindelige terrorister var mange, og de kom fra et utal af grupperinger og partier, men forfatteren har valgt at koncentrere sin undersøgelse om kvindelige medlemmer af Det Social Revolutionære Parti, der senere kom til at spille en vigtig rolle i den russiske revolution. På grund af partiets voldelige udgangspunkt er det overraskende, at det havnede på det revolutionære demokratis side og ikke hos bolsjevikkerne, men det er en anden historie.

På baggrund af en minutiøs læsning af en række udvalgte biografier kan forfatteren til sidst slå fast, at der snart udvikledes en genre, der hentede byggesten i de ældre biografier og udviklede dem i forskellige retninger alt efter forfatternes baggrunde, politiske ståsteder og tidsånden. Der er variationer, men grundstrukturen 
er overraskende ens, og forfatteren argumenterer overbevisende for, at genren og konventionerne tager overhånd over »den virkelige historie«. Selv når der er tale om selvbiografier. Hun kan også konstatere, at der er afgørende forskelle på, hvordan den kvindelige og mandlige helt tager sig ud. I begge tilfælde, er det dog middelklasseidealet, der danner skole, også selv om helten måtte komme fra bondestanden eller arbejderklassen, hvilket dog mere var undtagelsen end reglen, og det er jo i sig selv en god forklaring på, at genren udviklede sig, som den gjorde.

Der er næppe tvivl om, at der ligger mange gode historier og gemmer sig i det omfattende materiale, som forfatteren lægger til grund for sin undersøgelse, men dem får læseren kun et svagt genskind af, fordi det ikke er dem, men deres konstruktion, deres narrativitet, der interesserer forfatteren. Hun dissekerer fortællingerne, vejer og tæller på en måde, der minder om de russiske formalisters behandling af litteraturen. Forfatteren forsikrer dog om, at hun er historiker og ikke litterat eller sprogforsker.

Omkring en fjerdedel af bogen er viet teoretiske overvejelser og en forskningsoversigt. Det skyldes selvfølgelig, at der er tale om en akademisk afhandling, hvor der jo stilles krav om den slags, men man må alligevel spørge, hvem der kan være interesseret $\mathrm{i}$ at læse disse afsnit andre end vejledere, bedømmere og kommende doktorander, men bogen retter sig vel til et bredere publikum, og hvis det er tilfældet, skulle disse afsnit have været reduceret i antal og samlet længde.

Den særligt interesserede læser vil desuden konstatere, at der snarere er tale om kortfattede referater af forskellige teorier og ikke en egentlig redegørelse og systematisk og tydelig brug af dem i analysen.

Bogen havde fortjent en grundigere redaktionel bearbejdning før udgivelsen. Det kunne have sparet læseren for de mange gentagelser, unødvendige forbehold og trælse vendinger som: "som allerede beskrevet" eller "Som vi senere skal se».

Forfatteren vil gerne gøre sin forskning anvendelig og hævder, at den med fordel vil kunne bruges af forskere, der beskæftiger sig med vore dages terrorisme, ligesom hun selv er blevet inspireret af moderne forskning. Det vil jeg ikke afvise, men man kunne frygte, at denne brugs- og samfundsfagligt orienterede metode efterhånden helt vil fortrænge ikke bare den gode historie, men også ambitionen om at nærme sig fortiden som den var, helt gik fløjten. 